\title{
De militante grupper truer fortsat i Mali
}

\section{Manni Crone}

\section{Islamistiske grupper havde måneder til at forbere- de sig på udenlandsk intervention, så i dag er trus- len fra dem mere dynamisk, kompleks og uforud- sigelig}

En række militante islamistiske grupper, der i 2012 havde erobret hele den nordlige del af Mali, var begyndt at rykke mod syd, da Frankrig i januar 2013 indledte en militær intervention imod dem. Islamisterne truede med at indtage en strategisk vigtig lufthavn i Sévaré og på sigt måske ligefrem hovedstaden Bamako.

Det er nok kommet bag på de fleste, at Danmark pludselig blev engageret i en krig i Mali med et Hercules-fly til rådighed for de franske styrker, for hvad er det overhovedet, der foregår i dette land? Og hvad er det for militante grupper, som den internationale intervention er rettet $\bmod$ ?

I 2012 havde de islamistiske grupper AQIM (al-Qaeda i Islamisk Maghreb), Ansar Dine samt Mujao (Bevægelsen for Enhed og Jihad i Vestafrika) taget kontrol med de tre store byer i Nordmali: Gao, Timbuktu og Kidal.

Disse grupper kom ikke udefra, men havde befundet sig i Nordmali $\mathrm{i}$ årevis. AQIMs algeriske emirer havde her fundet et fristed, hvor de kunne spinde guld på narkosmugling og kidnapninger, og lederne af Ansar Dine var lokale tuareger fra Kidal. Men i 2012 opstod der en ny situation, som banede vejen for, at disse grupper kunne erobre Nordmali og gennemføre deres fælles politiske projekt, nemlig et sharia-baseret styre.

\section{Tuaregoprør og statskup}

2012 skulle blive et sandt annus horribilis for Mali, der havde været regnet for at være et stabilt mønsterdemokrati i Vestafrika. I januar 2012 havde tuaregerne i Nordmali startet 
et oprør. Siden Fransk Sudan i 1960 blev selvstændigt under navnet Mali, havde den nordlige, ørkenrige del af landet, hvor tuaregerne holder til, været økonomisk marginaliseret, og derfor havde tuaregerne med jævne mellemrum gjort oprør.

De to seneste oprør i 1992 og 2006 var mundet ud i nogle fredstraktater, som lovede øget selvstyre til den nordlige del af Mali, samt at tuaregerne i højere grad skulle integreres i Malis nationale hær. Men de privilegier, som fulgte med en øget decentralisering, blev monopoliseret af en lille, snæver elite. Visse tuaregledere blev forgyldt, mens andre blev forbigået, og det gav anledning til frustration.

Oprøret i 2012 var dog delvist udløst af situationen i Libyen. Der var en lang tradition for, at tuareger fra Mali og Niger drog til Libyen for at blive lejesoldater i Gaddafis hær. Men da Gaddafis regime brød sammen i 2011, flygtede disse tuareger med tunge våben og kamperfaring tilbage til Mali, hvor de gik i gang med at forberede et oprør.

I slutningen af 2011 havde de samlet forskellige tuareggrupper til én nationalistisk separatistbevægelse, MNLA (Den nationale Bevægelse for Befrielse af Azawad). MNLA ønskede ikke flere politiske aftaler med Malis regering, men ville denne gang kæmpe for Nordmalis eller 'Azawads' selvstændighed.

Den erfarne tuaregleder Iyad ag Ghali, der havde været med til at starte to tidligere oprør, så sig selv som den naturlige leder af MNLA. Men under intern rivalisering blandt tuaregerne blev han imidlertid vraget til posten. Da han samtidig blev forbigået som leder af Ifoghas-klanen, valgte han i slutningen af 2011 at danne sin egen militante gruppe, Ansar Dine, som i modsætning til den nationalistiske gruppe MNLA havde en islamistisk dagsorden.

Selv om de to tuareggrupper MNLA og Ansar Dine havde forskellige mål, kæmpede de i starten af oprøret side om side og fik hurtigt drevet Malis hær ud af det nordlige Mali. Hærens sammenbrud i nord førte den 22. marts til et militærkup i hovedstaden Bamako. Yngre officerer fra 'de røde baretter' var stærkt utilfredse med den udbredte korruption i regeringen og navnlig, at de såkaldt 'grønne baretter', der havde et tæt forhold til præsidenten, blev favoriseret.

Et mytteri i en militærgarnison i Kati syd for Bamako udviklede sig den 22. marts til et decideret statskup. Kuppet blev officielt retfærdiggjort med, at regeringen ikke havde givet hæren tilstrækkelige midler til at sikre det nordlige Mali. Det betød enden på 20 års demokratisk styre, som i stigende grad var blevet præget af korruption.

De vestafrikanske ECOWAS-lande fik hurtigt presset kuplederen Amadou Sanogo til at træde tilbage. Det skete på betingelse af, at han kunne være med til at håndplukke en ny 
regering og i det hele taget bevare en magtfuld position i kulisserne af det politiske liv.

Hærens kollaps i nord førte til, at MNLA den 6. april kunne erklære hele den nordlige del af Mali - Azawad - for selvstændigt. Men knap var sejrsflagene hejst, før MNLA blev snigløbet af deres tidligere allierede fra Ansar Dine, som nu havde fundet nye legekammerater i de islamistiske grupper AQIM og Mujao.

Denne udvikling skyldes dels intern rivalisering blandt tuaregerne, dels at MNLA gik meget hårdhændet til værks. Fodfolket i MNLA bestod delvist af 'fremmede', der havde været mange år i Libyen, og som ikke afholdt sig fra at plyndre og voldtage 'deres egne'. Det er således sandsynligt, at der i befolkningen har været en vis efterspørgsel efter, at de islamistiske grupper i statens fravær gik ind og ydede beskyttelse $\bmod$ MNLA.

\section{AQIM og Mujao}

I løbet af juni og juli blev MNLA således drevet ud af de store byer $\mathrm{i}$ nord, som de islamistiske grupper herefter $\mathrm{i}$ al fordragelighed kunne fordele imellem sig. Mujao regerede i Gao, Ansar Dine kontrollerede tuaregbyen Kidal, mens AQIM og Ansar Dine samarbejdede om at regere i den historiske by Timbuktu.

AQIM er oprindeligt en algerisk oprørsbevægelse, mens Mujao, der blev dannet i 2011 som en udbryder- gruppe af AQIM, har mauretanske ledere. Begge grupper opererer på kryds og tværs af grænser i hele Sahara. Ansar Dines er derimod en lokal gruppe, hvis ledere er tuareger fra Kidal.

Det giver dog ikke mening at tale om 'fremmede' versus 'maliske' grupper. Regeringer i Mali og Algeriet har forsøgt at skabe et skel mellem de 'fremmede terrorgrupper', der skulle bekæmpes, og de 'lokale tuareggrupper' fra Mali, som man skulle forhandle med.

Men selv om AQIM oprindeligt stammer fra Algeriet, og Mujao har mauretansk ledelse, er disse grupper på hjemmebane i Nordmali.

AQIM har befundet sig i Nordmali i over 10 år, og gruppen har haft en meget bevidst strategi om at blive integreret i området. AQIM's medlemmer har giftet sig ind i lokale familier, og mange af de penge, de har tjent på smugleri og kidnapninger, er blevet brugt til at hjælpe de fattige. AQIM har fx betalt overpris for varer, udstyret folk med telefoner og SIM-kort og har sørget for medicin og lægehjælp til de fattige.

AQIM er altså ikke en fremmed terrorgruppe, der er kommet udefra og har tvunget sharia ned over hovedet på de lokale, men en gruppe, som over de sidste 10 år har slået sig ned i Nordmali og har haft en social funktion i området.

AQIM blev oprindeligt dannet i 2006, da den militante algeriske oprørsgruppe GSPC sluttede sig til al- 
Qaeda og tog navnet al-Qaeda i Islamisk Maghreb. I dag, hvor de militante grupper er trængt i defensiven i Nordmali, er det formentlig AQIM, som har størst kapacitet og modstandsdygtighed, og det skyldes bl.a. gruppens lange erfaring med borgerkrig, terrorisme og asymmetrisk krig.

Strengt taget går AQIM's historie nemlig tilbage til 1991, hvor et autoritært algerisk militærregime annullerede et demokratisk valg, fordi det islamistiske parti FIS (Front Islamique du Salut) var gået af med sejren. På den baggrund valgte dele af FIS at gå under jorden og danne den væbnede gruppe GIA (Groupe Islamique Armée). Dannelsen af GIA faldt sammen med, at mange algeriske mujahideen, der havde været i Afghanistan for at kæmpe mod Sovjetunionen, vendte tilbage til Algeriet med militant erfaring og en meget rigoristisk forståelse af islam (salafisme).

GIA førte guerillakrig mod den algeriske stat, men udførte også ekstremt voldelige angreb mod civile, som ikke levede op til deres religiøse standarder. Internt i GIA var der utilfredshed med denne ekstreme vold mod civile, som gjorde GIA upopulær i befolkningen.

På den baggrund opstod i 1998 udbrydergruppen GSPC (Groupe salafiste pour la prédication et le combat), der koncentrerede sig om at lave attentater mod den algeriske stat. I takt med at Algeriet optrappe- de sine anti-terrorbestræbelser, blev GSPC trængt mod syd og begyndte derfor at udvide sin aktionsradius i Sahara. Denne udvikling skyldtes først og fremmest Mokhtar Belmokhtar, der omkring 2000 sluttede sig til GSPC og herefter organiserede en militant gruppe (katiba), som opererede i det sydlige Algeriet og Nordmali.

Belmokhtar havde startet sin karriere i en træningslejr i Afghanistan omkring 1990, men var i 1993 vendt tilbage til Algeriet, hvor han først havde været med i GIA, derefter GSPC og AQIM. Han er altså en professionel militant med lang erfaring, som primært har ageret i Sahel-området. Her han har han været involveret i 'gangster-jihadisme' i form af cigaret- og narkosmugling, hvilket har givet ham øgenavnet 'Mr. Marlboro'.

\section{Regional al-Qaeda-gruppe}

Efter terrorattentatet i New York den 11. september 2001 var der personer i GSPC, som ønskede, at gruppen skulle slutte sig til al-Qaeda, og da amerikanske tropper i 2003 gik ind i Irak, fik denne fraktion vind i sejlene. I 2004 overtog Abdelmalek Droukdel ledelsen af GSPC. Han bejlede til al-Qaedas ledelse, og i 2006 blev GSPC til al-Qaeda i Islamisk Maghreb.

Der var dog ikke kun tale om et navneskifte, men også delvist om en ny strategi. Som nyslået al- Qaeda- 
gruppe havde AQIM ambitioner om at ramme det, der i al-Qaedas terminologi hedder 'den fjerne fjende', dvs. vestlige mål. De har dog hidtil afholdt sig fra angreb i Europa. I stedet har gruppen slået sig på at tage vestlige statsborgere som gidsler $i$ Sahel-regionen, og i de fleste tilfælde har det indbragt store løsesummer.

Da GSPC midlertidigt havde tabt den nationale kamp i Algeriet og var trængt ned i Sahel, kunne gruppen bruge al-Qaedas brand som led i en regionaliserings- og internationaliseringsstrategi. GSPC kunne nu fremstå som en potent, regional al-Qaeda-filial og ikke blot som en falleret algerisk oprørsgruppe.

I Nordmali havde AQIM som sagt fundet et fristed uden for algerisk territorium. Så længe AQIM ikke rettede angreb mod Malis stat og afstod fra at tage gidsler på Malis territorium, vendte Malis regering det blinde øje til. Ofte blev gidsler, der var taget til fange i nabolandene, overflyttet til Nordmali, hvor regeringen så kunne høste diplomatisk anerkendelse ved at få gidslerne frigivet.

\section{Velgørenhedsorganisation}

De store summer fra gidseltagninger er som sagt bl.a. blevet brugt til at købe goodwill i Timbuktu, hvor AQIM primært holdt til. Her fungerede AQIM som en slags islamisk velgørenhedsorganisation, der tog vare på de fattige og spenderede penge på de lokale marabouter (religiøse autoriteter), der blev udstyret med biler, penge og våben

De seneste år har AQIM's aktiviteter i 'region syd' dog været præget af intern konkurrence mellem de to emirer i Sahara-zonen, Mokhtar Belmokhtar og Abu Zeid. AQIM's øverste emir i Algeriet, Abdelmalek Droukdel, anså Belmokhtar for at være for uafhængig og forsøgte i flere omgange at sende regionale emirer ned til Sahara for at sætte ham på plads.

Belmokhtar nægtede imidlertid at indordne sig under en struktur med en overordnet, der var udsendt fra Algeriet. I oktober 2012 kom det til et regulært brud med AQIM, og Belmokhtar dannede kort efter en ny militant gruppe (katiba) - "dem, der underskriver med blod" -, som bare få dage efter den franske intervention stod bag den store gidselaffære på et gasanlæg i Algeriet.

Et brud betyder dog ikke nødvendigvis, at grupperne ikke fremover kan arbejde sammen. Der foregår løbende en fragmentering af de militante grupper i området. Visse grupper splittes op, nye opstår, og alliancer kan skiftes ud fra den ene dag til den anden.

Denne konstante fragmentering skyldes sjældent ideologiske uoverensstemmelser, men oftere personlig rivalisering, penge eller opportunisme. Mujao og Belmokhtars gruppe har begge brudt med AQIM i 
henholdsvis 2011 og 2012, hvilket dog ikke forhindrer dem i i dag at kæmpe side om side med AQIM.

\section{Islamistisk tuareggruppe}

Selv om AQIM og Mujao er al-Qaeda-relaterede grupper med en bredere regional og international dagsorden, havde disse grupper alligevel et udmærket samarbejde med den islamistiske tuareggruppe Ansar Dine, der var dannet i 2011 for at tilfredsstille Iyad ag Ghalis personlige ambitioner. Ghali var en slags opkomling, der ikke kom fra Ifoghasstammens ledende familier, men tilhørte en ny generation af tuaregledere - de såkaldte big men -, der som eks-rebeller eller narkosmuglere havde opbygget en position, hvor de stod i et modsætningsforhold til de traditionelle autoriteter.

I løbet af 2012 havde Ansar Dine en central placering, fordi gruppen med stor snilde forstod at spille på flere heste. På den ene side havde Ansar Dine en tæet alliance med AQIM og Mujao om at regere i Nordmali, men på den anden side deltog gruppen løbende i politiske forhandlinger med regeringerne $i$ Mali, Algeriet og Burkina Faso. Disse lande ønskede at isolere 'terrorgrupperne' og finde en politisk løsning på konflikten i Nordmali ved at lave en deal med MNLA og Ansar Dine.

Iyad ag Ghali havde oprindeligt startet sin karriere i Libyen i begyn- delsen af 1980'erne, hvor han var indrulleret i Gaddafis hær. I slutningen af 1980'erne kom han tilbage til Mali og var med til at starte tuaregoprørene i 1990 og 2006. Ag Ghali har altid haft en meget pragmatisk tilgang til konflikter og været indstillet på at finde politiske løsninge, især hvis det kunne tjene hans egne interesser. Han spillede således en afgørende rolle i de politiske forhandlinger, som i 1991 og 2006 førte til de kontroversielle fredstraktater. Ved flere lejligheder fungerede han også som forhandler, når GSPC Belmokhtar eller Abu Zeid - havde taget gidsler i regionen og overført dem til Nordmali, og ved flere lejligheder lykkedes det ham at få frigivet gidslerne.

Som sagt er Ansar Dine en islamistisk tuareggruppe, hvis politiske program først og fremmest gik ud på at indføre sharia i de områder, gruppen kunne erobre. Ansar Dine har hele tiden været villig til at indgå $\mathrm{i}$ politiske forhandlinger, men har samtidig understreget, at der var ét punkt, som ikke stod til forhandling, nemlig sharia.

Det er da også netop spørgsmålet om sharia, som i ideologisk forstand adskilte Ansar Dine fra den sekulære tuareggruppe MNLA. Ud over personlige skærmydsler mellem lederne fra de to grupper er deres politiske projekter nemlig direkte modstridende.

MNLA havde i udgangspunktet et sekulært, nationalistisk projekt, idet 
de kæmpede for en selvstændig tuaregstat i Azawad. Ansar Dine kæmpede ikke for en stat til tuaregerne, som er dybt splittede, men for et sharia-baseret styre. Og da sharia ikke kender nogen grænser, er deres projekt ikke knyttet til en specifik nation eller et specifikt territorium.

\section{Religionens betydning}

Sharia er et komplekst begreb, der kan forstås og fortolkes på et utal af måder. I lighed med al- Qaeda-grupperne har Ansar Dine en salafistisk forståelse af sharia, hvor sharia opfattes som en lov, der skal implementeres med eventuel støtte fra et islamisk politi.

Man skal dog ikke overvurdere religionens betydning. Lederne af de salafistiske grupper er ikke religiøse fanatikere, men først og fremmest erfarne, professionelle militante, der har været involveret i borgerkrige, oprør, terroraktioner og gidseltagninger i årevis. De er derfor vant til at befinde sig i en kontekst, hvor deres chance for at overleve afhænger af deres evne til at manøvrere i en specifik strategisk situation, og hvor de hele tiden er afhængige af den lokale befolkning.

Internt i AQIM foregik der diskussioner om, hvorvidt det var klogt eller ej at gennemføre de hårdeste sharia-straffe. AQIM's øverste emir i Algeriet, Droukdel, udsendte fx en erklæring, hvor han opfordrede AQIM's emirer til at fare lempeligt frem og være meget forsigtig med at eksekvere de hårdeste sharia-straffe. Han foreslog ligefrem, at man skulle lade Ansar Dine være ansvarlig for at gennemføre straffe, mens AQIM på dette område skulle holde sig diskret i baggrunden.

Fra tiden i GIA havde Droukdel lært, at overdreven vold mod civile kan blive et problem for en organisation, som er afhængig af at være på god fod med lokalbefolkningen. I den tid AQIM regerede i Timbuktu, gennemførte gruppen en enkelt amputation i modsætning til den yngre og mindre erfarne gruppe Mujao, som gennemførte $15 \mathrm{ampu}$ tationer i Gao.

Den militante praksis er altså ikke styret af en abstrakt, ideologisk forståelse af islam, men derimod af pragmatiske overvejelser samt en evne til at tilpasse sig den konkrete situation.

\section{Efter invasionen}

Der er ingen tvivl om, at den internationale intervention har været et hårdt slag for de militante grupper, der for blot få måneder siden havde kronede dage i Nordmali.

De har nu foretaget en 'taktisk tilbagetrækning'. Nogle er flygtet ud af landet, andre har forskanset sig i Ifoghas-massivet i den nordøstlige del af Mali. Her er de belejret af specialtropper fra Frankrig og Tchad, der råder over avanceret efterretningsudstyr, herunder amerikanske 
overvågningsdroner. Dertil kommer, at mange af de militante, bl.a. AQIMemiren Abu Zeid, er blevet dræbt.

Hvad angår Ansar Dine er gruppen i opløsning. Tuaregerne er kendt for stor taktisk fleksibilitet, og da franske tropper nærmede sig Kidal, fandt Ifoghas-klanens leder, Alghabass ag Intalla, det opportunt at bryde med høgene omkring Ghali. I stedet dannede han MIA (Azawads Islamiske Bevægelse), der nu tager skarpt afstand fra 'terrorgrupperne' og bejler til den tidligere modstander MNLA, som igen er den stærke tuareggruppe i Kidal.

Men selv om de militante islamistiske grupper er trængt i defensiven, råder de alligevel over en række fordele, som man ikke skal undervurdere.

For det første har de haft god tid til at planlægge og koordinere, hvordan de skulle reagere på en intervention. Siden ECOWAS i september 2012 anmodede FN om en resolution, der gjorde interventionen mulig, har udsigten til at det ville ske, været på bordet. De militante grupper har altså haft månedsvis til at planlægge, hvordan de skulle håndtere forskellige scenarier i forbindelse med en intervention. De har indrettet sig i Ifoghas-massivet med skjulesteder og bombeværksteder, og den store gidselaffære i Algeriet i januar 2013, som Belmokhtar stod bag, var ikke flikket sammen i al hast, men havde været planlagt i månedsvis.
Dertil kommer, at de militante, som nu befinder sig i Ifoghas-massivet, udgør en lille elite af professionelle og dedikerede militante, hvoraf nogle har lang erfaring med borgerkrig, ørkenkrig, terrorisme og andre former for asymmetrisk krigsførelse. De kender området på kryds og tværs og er vant til et spartansk liv i ørkenen, hvor man sover på jorden og lever under meget ringe hygiejniske forhold. Desuden har de erfaring med ørkenkrig, hvilket med undtagelse af soldater fra Tchad - ikke gælder deres modstandere.

Selv om AQIM, Mujao, Ansar Dine og Belmokhtars katiba er trængt i defensiven i Ifoghas-massivet, er de stadig i stand til at føre asymmetrisk krig. I løbet af de sidste måneder har især Mujao været $\mathrm{i}$ stand til at gennemføre flere selvmordsangreb i de tre store byer $\mathrm{i}$ Nordmali. Disse attentater vidner om, at grupperne stadig har en vis opbakning i befolkningen, idet nogle af attentaterne blev gennemført med våben, der var skjult hos lokale i byerne.

\section{Truslen mere kompleks}

Selv om den franske 'operation Serval' sigter mod at 'genetablere Malis territoriale integritet', er konflikten ikke længere begrænset til Mali. Det viste det store terrorangreb i Algeriet med al tydelighed. Den største trussel mod vestlige mål i regionen i 
dag kommer dog ikke kun fra de grupper, som i 2012 befandt sig i Nordmali, men også fra deres vidt forgrenede netværk af støtter og sympatisører.

Det betyder, at denne trussel i dag er blevet mere dynamisk, kompleks og uforudsigelig. I februar 2013 tog Ansaru fra Nigeria en række vestlige og libanesiske gidsler til fange i det nordøstlige Nigeria, som gengæld for 'aggression mod islam i Afghanistan og Mali', og efterfølgende har disse grupper taget syv franskmænd, herunder fire børn, som gidsler i Cameroun, ligeledes som gengæld for 'krigen mod islam i Mali'.

De militante islamistiske grupper fra Nigeria, Boko Haram og Ansaru, har tidligere haft direkte kontakt med AQIM, idet medlemmer af disse grupper i 2012 fik træning i Timbuktu-området. Da den franske in- tervention startede, hastede de tilbage til Nigeria.

Sidst men ikke mindst har de militante grupper tiden på deres side. De kan gå under radaren og vente på gunstigere tider. I modsætning til den franske hær, der har travlt med at komme ud af en omkostningsfuld konflikt, hvor franske boots on the ground aldrig har været et ønskescenario, og hvor opbakningen i Frankrig svinder dag for dag. Det er derfor ikke overraskende, at Frankrig nu presser på for at få et FN-mandat til en fredsbevarende styrke med et offensivt mandat.

Manni Crone er seniorforsker ved DIIS med Mellemøsten som hovedområde. Ekspert i terrorisme, Nordafrika og Sahel, Mali, ekstremisme, radikalisering og islamisme. 